Simposium I Jaringan Perguruan Tinggi untuk Pembangunan Infrastruktur Indonesia, 2016

\title{
Analisis Kinerja Pelayanan Pemanduan Kapal Terhadap Waktu Tunggu (Waiting Time) Di Pelabuhan Tanjung Perak
}

\author{
Yudha Andrianto ${ }^{\mathrm{a} *}$, Achmad Wicaksono $^{\mathrm{b}}$, M. Ruslin Anwar ${ }^{\mathrm{a}} \mathrm{b}$ \\ ${ }^{\mathrm{a}}$ Mahasiswa, Program Magister, Jurusan Teknik Sipil, Fakultas Teknik, Universitas Brawijaya \\ ${ }^{b}$ Dosen, Jurusan Teknik Sipil, Fakultas Teknik, Universitas Brawijaya \\ ${ }^{a, b}$ Dosen, Jurusan Teknik Sipil, Fakultas Teknik, Universitas Brawijaya \\ Jl. MT. Haryono 167, Malang 65145, Indonesia \\ Korespondensi: yudha.andrianto86@gmail.com
}

\begin{abstract}
Abstrak
Pelabuhan Tanjung Perak terintegrasi dengan Pelabuhan Teluk Lamong, Gresik, Socah dan Bulupandan sebagai penunjang memperlancar kegiatan arus lalu lintas transportasi angkutan laut dan penggerak dalam meningkatkan pertumbuhan ekonomi di Jawa Timur. Kinerja operasional pelabuhan menggambarkan tingkat pelayanan yang meliputi pelayanan kapal (labuh, tambat, pandu, tunda dan air) dan pelayanan barang (jasa dermaga dan penumpukan). Ketepatan waktu untuk dapat bersandar di dermaga merupakan penilaian kinerja pelayanan pemanduan kapal, karena mempengaruhi waktu tunggu. Penelitian ini untuk mengetahui kondisi eksisting pelayanan pemanduan kapal dan memberikan strategi perbaikannya. Metode yang digunakan dalam penelitian ini adalah IPA dan SWOT secara subjektif. Hasil penelitian kinerja pelayanan pemanduan di pelabuhan Tanjung Perak saat ini dinilai tidak sesuai dengan standar kinerja, terdapat sebanyak 5.883 kapal dari 8.956 jumlah kunjungan kapal dalam 1 tahun memiliki waktu tunggu lebih dari 2 jam. Persepsi pengguna jasa tidak puas terhadap kinerja pelayanan pemanduan kapal, dinilai penting untuk tingkat kepentingannya. Hal-hal pada aspek pelayanan pemanduan kapal yang penting, dinilai tidak puas tingkat kinerjanya yaitu ketepatan pelayanan dokumen, SBNP, ketersediaan kapal tunda/pandu dan ketersediaan failitas untuk petugas pandu. Beberapa hasil analisis dan wawancara menjadi faktor eksternal dan internal permasalahan yang timbul pada pelayanan pemanduan kapal untuk mendapat strategi perbaikan yaitu perlu adanya pembaharuan SISPRO pemanduan kapal serta kerjasama di bidang usaha penyediaan fasilitas operasional pelaksanaan pelayanan pemanduan kapal ataupun untuk menyediakan perawatan alur pelayaran, mengurangi waktu tunggu yang berdampak pada biaya (cost) yang selama ini merugikan dunia usaha dan konsumen.
\end{abstract}

Kata kunci : kinerja pemanduan, IPA, SWOT, Pelabuhan Tanjung Perak.

\section{Pendahuluan}

Transportasi laut merupakan salah satu sarana transportasi yang sangat murah dan dapat meningkatkan kegiatan ekspor dan impor maupun perdagangan domestik. Dengan demikian pentingnya sebuah pelabuhan untuk menghubungkan antar moda transportasi laut dengan moda transportasi darat.

Pelabuhan Tanjung Perak terintegrasi dengan Pelabuhan Teluk Lamong, Gresik, Socah dan Bulupandan sebagai penunjang memperlancar kegiatan arus lalu lintas transportasi angkutan laut dan sebagai penggerak dalam meningkatkan pertumbuhan ekonomi di Jawa Timur.

Kinerja operasional pelabuhan merupakan gambaran dari prestasi atau hasil kerja suatu pelabuhan pada periode tertentu, sehingga akan menggambarkan tingkat pelayanan yang diberikan kepada pengguna jasa yang meliputi pelayanan kapal (labuh, tambat, pandu, tunda dan air) dan pelayanan barang (jasa dermaga dan penumpukan).

Pengaruh dari waktu tunggu yang lama dapat menyebabkan kerugian mencapai sekitar Rp 7 juta per hari per kapal yang cukup merugikan pengguna jasa. Tidak hanya membengkaknya biaya, waktu tunggu (waiting time) berakibat juga pada produksi barang dan sebagian pekerja tidak dapat berkerja akibat menunggu bahan baku produksi jika kedatangan kapal sampai mengeluarkan barang/petikemas (container) memerlukan waktu yang cukup lama hingga 20 hari sehingga dapat merugikan pemilik barang (consignee)/pembeli (buyer)[1].

\subsection{Batasan Masalah}

Batasan masalah penelitian ini adalah:

a. Waktu tunggu layanan pandu (approach time) yang dianalisa untuk kapal wajib pandu dan hanya melakukan kegiatan olah gerak kapal khususnya pada APBS (Alur Pelayaran Barat Surabaya);

b. Perhitungan kinerja waktu hanya diberlakukan pada personel pandu pada PT. Pelabuhan Indonesia III (Persero) yang melayani kapal wajib pandu;

c. Pengguna jasa yang dimaksud pada penelitian ini hanya pada perusahaan angkutan laut yang mengajukan permintaaan pandu dan tunda;

d. Waktu tunggu yang disebabkan oleh pengurusan administrasi di pelabuhan (postpone time) pada penelitian ini hanya pada waktu pengurusan administrasi dokumen PPKB (Permintaan Pelayanan Kapal dan Barang);

\footnotetext{
* Corresponding author.

E-mail address: yudha.andrianto86@gmail.com
} 
e. Kunjungan kapal yang dianalisa hanya pada kapal yang akan melakukan kegiatan sandar pada Terminal Umum di Pelabuhan Tanjung Perak bukan pada PELRA (Pelabuhan Rakyat), TUKS (Terminal Untuk Kepentingan Sendiri atau TERSUS (Terminal Khusus);

f. Kunjungan kapal yang tidak dianalisa adalah kapal-kapal wajib pandu dengan status liner voyage atau kapal-kapal yang mendapat dispensasi pandu.

\subsection{Tujuan Penelitian}

Tujuan penelitian ini adalah:

a. Mengetahui kondisi eksisting kinerja pelayanan pemanduan pada Pelabuhan Tanjung Perak;

b. Mengetahui persepsi pengguna jasa dan stakeholder terkait pemanduan kapal berdasarkan tingkat kepentingan dan tingkat kinerja saat ini di Pelabuhan Tanjung Perak;

c. Mengetahui strategi-strategi perbaikan pelayanan pemanduan kapal di Pelabuhan Tanjung Perak berdasarkan hasil analisis dan wawancara dengan pengguna jasa dan stakeholder terkait.

\section{Metode Penelitian}

Untuk dapat lebih mengarahkan pada jalannya penelitian dan dapat menghasilkan hasil penelitian yang cermat dan teliti, maka dibuatlah bagan alir penelitian sebagai pedoman dalam pelaksanaannya. Adapun dalam penelitian ini pelaksanaan penelitian dijelaskan dalam gambar 1.(a) sebagai berikut:

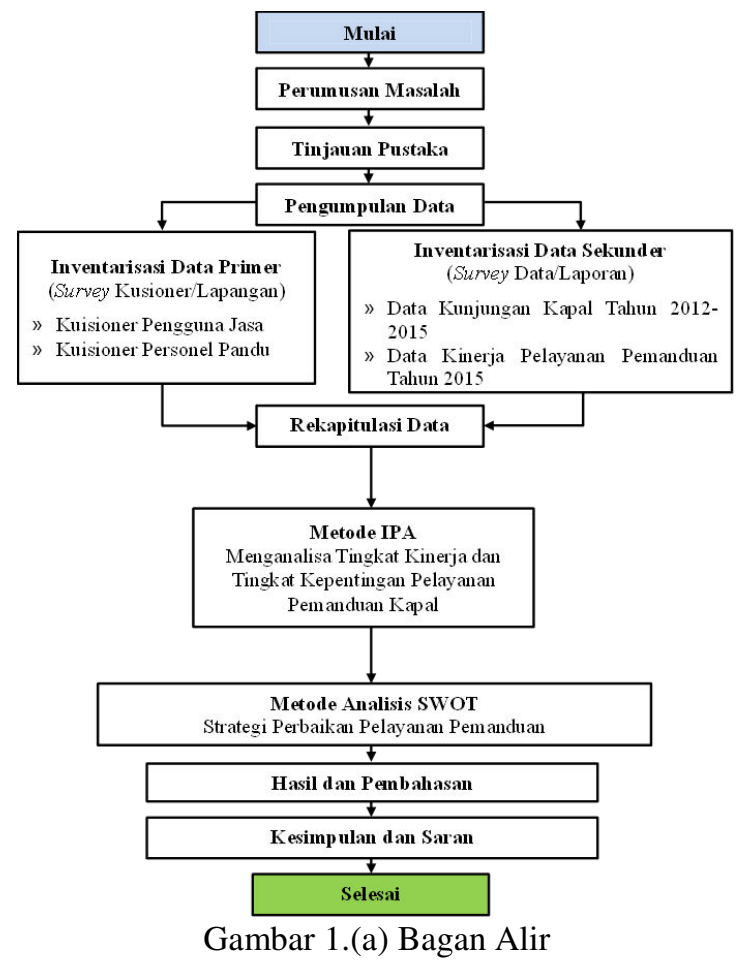

\subsection{Metode Pengumpulan Data}

Metode yang digunakan dalam pengumpulan data adalah:

a. Wawancara

Metode pengumpulan data dengan cara tanya jawab atau wawancara langsung, sebelumnya telah dibuat terlebih dahulu kemudian ditujukan kepada responden untuk dapat memberikan keterangan yang diperlukan atau dapat dilakukan kepada pihak yang ditunjuk untuk mewakili guna memberikan keterangan berhubungan dengan kinerja pelayanan pemanduan kapal di Pelabuhan Tanjung Perak.

b. Kuesioner

Metode pengumpulan data dengan cara menyusun dan mengajukan daftar pertanyaan kepada pihak responden secara tertulis sehingga memudahkan peneliti dalam pengolahan data guna mempersingkat waktu penilitian ini. Pada penelitian ini menggunakan kuisioner metode IPA untuk mengetahui persepsi responden berdasarkan tingkat kepentingan dan tingkat kepuasan pelayanan pemanduan kapal. 
c. Studi Pustaka

Mempelajari buku-buku referensi yang ada hubungannya dengan obyek yang diteliti. Ini dilakukan untuk memperoleh dasar-dasar teoritik mengenai masalah kualitas pelayanan terhadap tingkat kepuasan pengguna jasa yang digunakan untuk menganalisis kenyataan yang ada pada obyek yang diteliti.

\subsection{Penentuan Jumlah Sampel}

Untuk menentukan jumlah sampel, digunakan rumus Slovin:

$\mathrm{n}=\frac{\mathrm{N}}{1+\mathrm{Ne}^{2}}$

dimana:

1 : konstanta

n : jumlah sampel

$\mathrm{N}$ : jumlah populasi $=100$ responden.

e : kelonggaran ketelitian yang dapat ditolerir $(10 \%=0,1)$

Maka diperoleh :

$\mathrm{n}=\frac{491}{1+491(0,1)^{2}}=99,79 \approx 100$ Responden

\section{Hasil Dan Pembahasan}

\subsection{Gambaran Umum Pelabuhan Tanjung Perak}

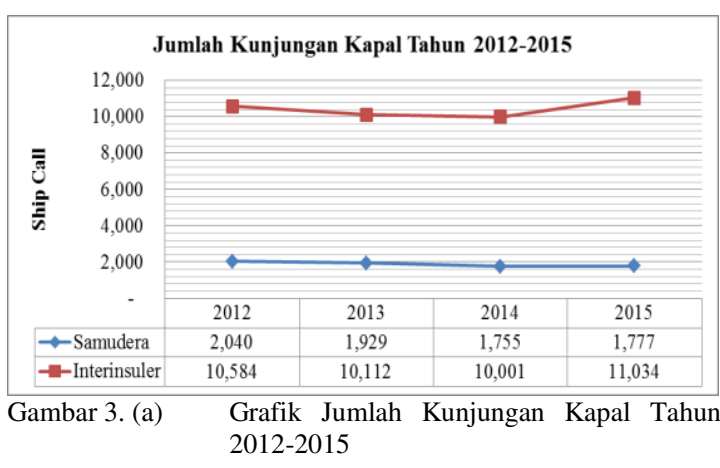

Peningkatan jumlah kunjungan kapal di Pelabuhan Tanjung Perak dari tahun 2014-2015.



Banyaknya jumlah kunjungan pada tahun 2015 untuk jenis kapal barang dengan tonnage yang besar.

\subsection{Kondisi Eksisting Waktu Tunggu (Waiting Time) Pelayanan Pemanduan Kapal}

Berdasarkan data sekunder terdapat lamanya waktu tunggu (waiting time) 2 jam lebih yang belum sesuai dengan standar yang ditentukan. Terlihat pada gambar 3. (c) di bawah. 


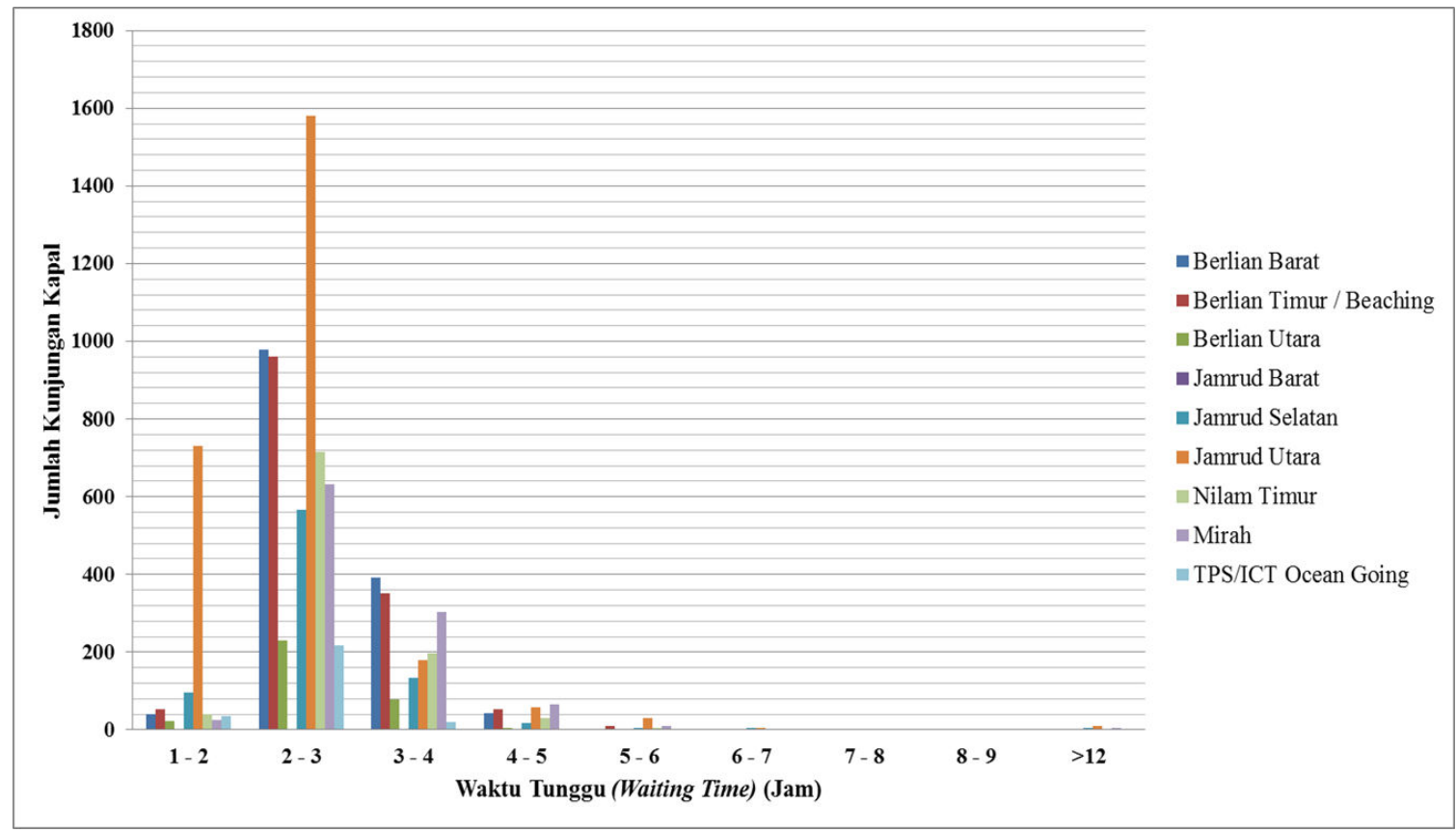

Gambar 3. (c) Diagram Waktu Tunggu (Waiting Time) dan Jumlah Kunjungan Kapal

\subsection{Analisis Deskriptif Gambaran Responden}

Penelitian ini menggunakan sampel 100 responden dari jumlah populasi sebanyak 491. Responden diambil dari pengguna jasa dan stakeholder terkait pelayanan pemanduan kapal di Pelabuhan Tanjung Perak. Berdasarkan data yang diperoleh dari hasil kuesioner, diperoleh analisis deskriptif gambaran responden secara umum adalah sebagai berikut:

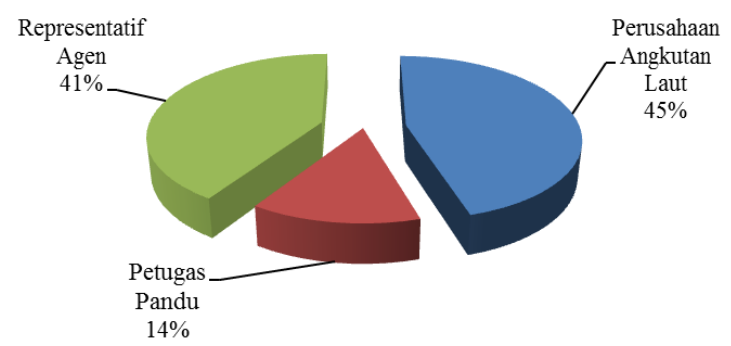

Gambar 3. (d) Grafik Status sebagai stakeholder

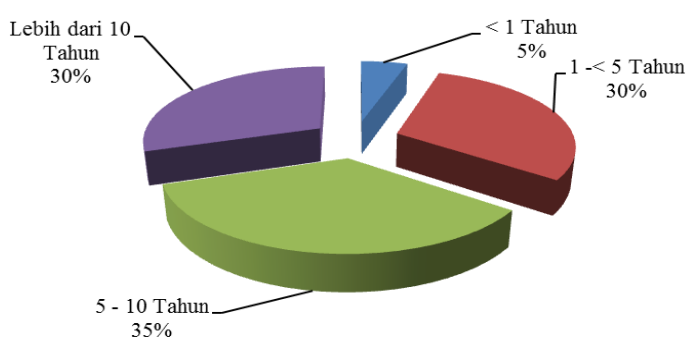

Gambar 3. (e) Grafik Lama menjadi Pengguna

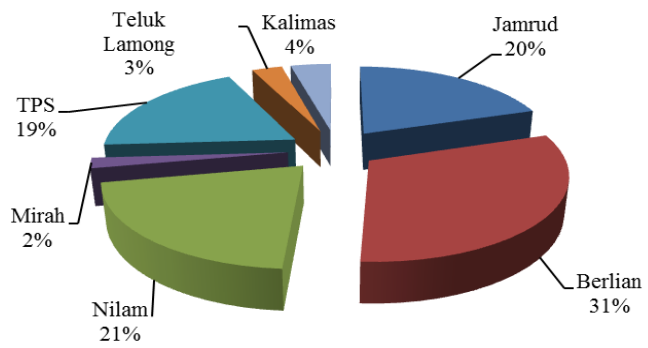

Gambar 3. (f) Grafik Terminal yang sering digunakan

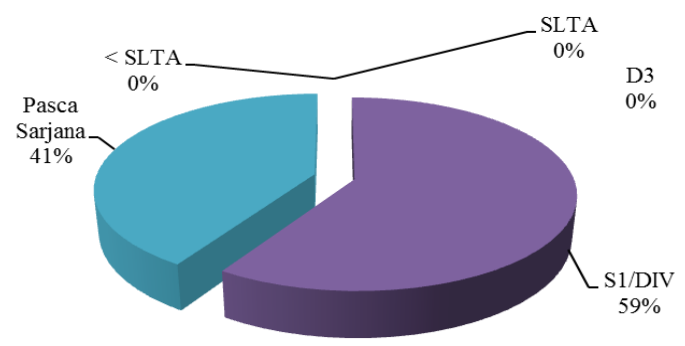

Gambar 3. (g) Pendidikan Terakhir

\section{Jenis Kelamin}

Hasil jenis kelamin dari responden sebanyak 100\% laki-laki. 


\subsection{Analisis Persepsi Pengguna Jasa Terhadap Pelayanan Pemanduan Kapal}

Pada penilitian ini terdapat 12 (dua belas) variabel tingkat kinerja dan tingkat kepentingan dalam pelayanan pemanduan kapal yang berdasarkan SISPRO dan kondisi di lapangan adalah sebagai berikut:

1) Aspek waktu tunggu kapal;

2) Aspek waktu pengurusan dokumen;

3) Aspek waktu pelayanan pemanduan;

4) Aspek SISPRO (Sistem dan Prosedur) Pelayanan Jasa Pemanduan;

5) Aspek kedalaman alur/kolam pelabuhan;

6) Aspek lebar/panjang alur/kolam pelabuhan;

7) SBNP (Sarana Bantu Navigasi Pelayaran);

8) Aspek keahlian petugas pandu dalam melakukan pemanduan;

9) Aspek ketersediaan kapal tunda/pandu;

10) Aspek jumlah dan kinerja petugas kepil di terminal;

11) Aspek kondisi fasilitas tambat di terminal (fender, bolder dan lainnya);

12) Aspek ketersediaan fasilitas petugas pandu.

Rekapitulasi Kuisioner Tingkat Kinerja dan Tingkat Kepentingan sebagai berikut: Tabel 1. Rekapitulasi Hasil Kuisioner

\begin{tabular}{|c|c|c|c|}
\hline No & Atribut & $\begin{array}{l}\text { Tingkat } \\
\text { kinerja }\end{array}$ & $\begin{array}{c}\text { Tingkat } \\
\text { kepentingan }\end{array}$ \\
\hline 1 & Waktu antrian (waiting time) kapal & 1.20 & 2.09 \\
\hline 2 & Ketepatan pelayanan dokumen & 1.36 & 4.21 \\
\hline 3 & Ketepatan waktu pemanduan kapal & 3.12 & 4.18 \\
\hline 4 & Sistem \& Prosedur (SISPRO) pemanduan kapal & 3.19 & 4.36 \\
\hline 5 & Kedalaman alur kolam & 3.56 & 4.32 \\
\hline 6 & Lebar/panjang alur kolam pelabuhan & 3.27 & 2.47 \\
\hline 7 & SBNP (Sarana Bantu Navigasi Pelayaran) & 2.13 & 4.22 \\
\hline 8 & Keahlian dan keterampilan petugas pandu & 2.91 & 3.48 \\
\hline 9 & Ketersediaan kapal tunda pandu & 2.25 & 4.41 \\
\hline 10 & Kesiapan petugas kepil di terminal & 2.81 & 2.35 \\
\hline 11 & Fasilitas-fasilitas sandar kapal di terminal & 2.73 & 2.17 \\
\hline 12 & Ketersediaan fasilitas untuk petugas pandu & 1.99 & 4.30 \\
\hline \multicolumn{2}{|r|}{ Rata-rata } & 2.54 & 3.55 \\
\hline
\end{tabular}

Dari hasil rata-rata pada tingkat kinerja dan tingkat kepentingan dari persepsi pengguna jasa bahwa tidak puas terhadap tingkat kinerja dan menyatakan penting akan aspek pelayanan pemanduan kapal, berdasarkan skala linkert pada tabel 2. di bawah ini.

Tabel 2. Skala Linkert

\begin{tabular}{|c|c|c|}
\hline Angka & Tingkat Kinerja & Tingkat Kepentingan \\
\hline 1 & Sangat Tidak Puas & Sangat Tidak Penting \\
\hline 2 & Tidak Puas & Tidak Penting \\
\hline 3 & Sedang & Biasa \\
\hline 4 & Puas & Penting \\
\hline 5 & Sangat Puas & Sangat Penting \\
\hline
\end{tabular}

Dengan hasil rekapitulasi data yang didapat di atas, maka untuk menjawab rumusan masalah mengenai persepsi pengguna jasa dan stakeholder terkait pelayanan pemanduan kapal dengan menggunakan metode IPA yang digambarkan pada gambar 3. (h) Hasil Kuadran Importance Performance Grid.

Adapun penjabarannya sebagai berikut:

» Kuadran I (Prioritas Utama) dengan tingkat kepentingan tinggi tapi tingkat kinerjanya rendah, yakni:

(2) Ketepatan pelayanan dokumen;

(7) Sistem SBNP (Sarana Bantu Navigasi Pelayaran) yang belum terintegrasi;

(9) Ketersediaan kapal tunda/pandu;

(12) Ketersediaan fasilitas untuk petugas pandu.

» Kuadran II (Pertahankan Prestasi) dengan tingkat kepentingan tinggi dan tingkat kinerjanya tinggi, yakni:

(3) Ketepatan waktu pemanduan kapal;

(4) Sistem \& Prosedur (SISPRO) pemanduan kapal;

(5) Kedalaman alur/kolam.

» Kuadran III (Prioritas Rendah) dengan tingkat kepentingan rendah dan tingkat kinerjanya rendah, yakni:

(1) Waktu antrian (waiting time) kapal. 
» Kuadran IV (Berlebihan) dengan tingkat kepentingan rendah tapi tingkat kinerjanya tinggi, yakni:

(6) Lebar/panjang alur/kolam pelabuhan;

(8) Keahlian dan keterampilan petugas pandu;

(10) Kesiapan petugas kepil di terminal;

(11) Fasilitas-fasilitas sandar kapal di terminal.

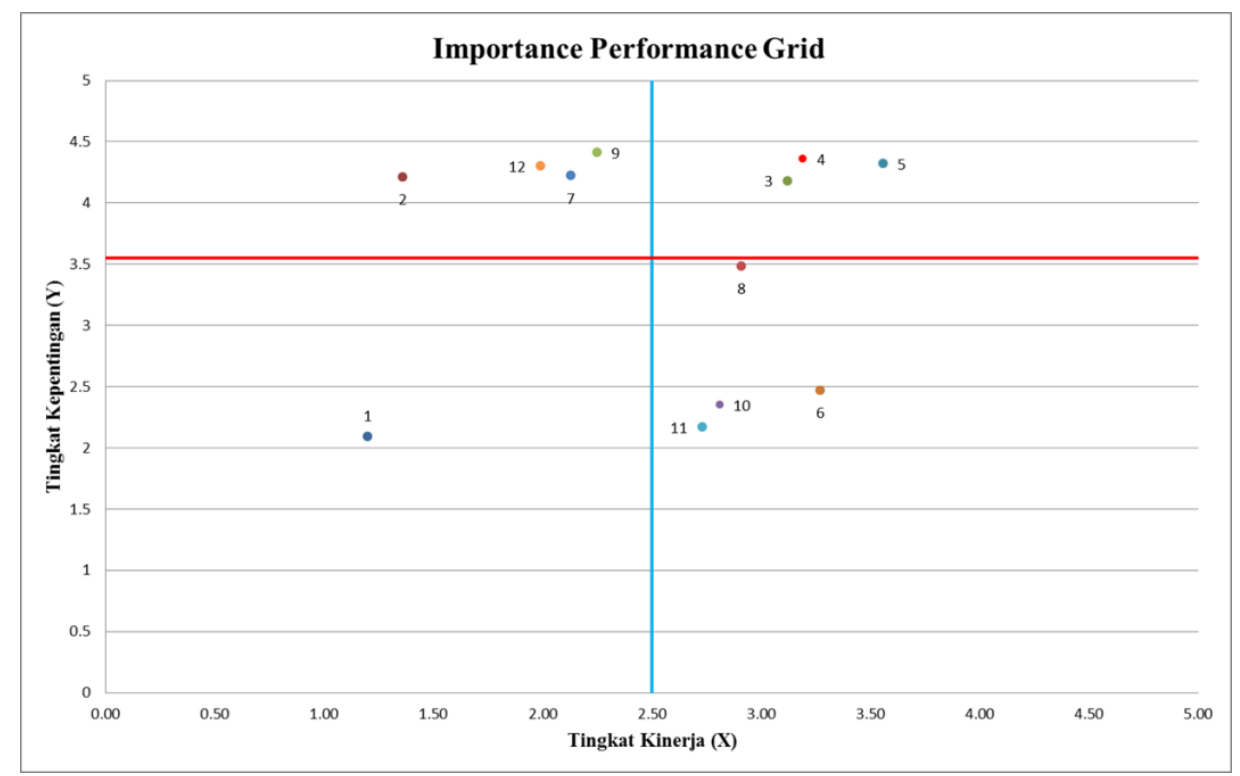

Gambar 3. (h) Hasil Kuadran Importance Performance Grid

\subsection{Strategi Perbaikan Kinerja Pelayanan Pemanduan Kapal dengan Menggunakan Metode Analisis SWOT} (Streght, Weakness, Opportunity dan Threat) secara Subjektif

Sebelum merumuskan strategi perbaikan kinerja pelayanan pemanduan kapal dengan matriks SWOT, terlebih dahulu akan disusun faktor strategi Internal dan Eksternal yang berpengaruh terhadap pelayanan pemanduan kapal. Faktor-faktor tersebut diperoleh dari hasil analisa IPA (Importance-Performance Analysis) dengan berdasarkan hasil wawancara dan observasi di lapangan dengan pengguna jasa dan stakeholder terkait yang didapat sebagai berikut:

» Kekuatan (Strength)

a. Ketepatan waktu pemanduan kapal (approach time) yang sudah sesuai dengan harapan pengguna jasa;

b. SISPRO (Sistem dan Prosedur) pemanduan kapal yang selalu dikoordinasikan dan disosialisasikan dengan baik;

c. Telah adanya program pengerukan alur/kolam yang dilaksanakan secara berkala;

" Kelemahan (Weakness)

a. Sistem yang terintegrasi pada pelayanan dokumen yang belum diterapkan;

b. Sistem kenavigasian yang belum terintegrasi dan belum digunakan secara maksimal;

c. Belum adanya cadangan kapal tunda/pandu apabila terjadi kerusakan atau perawatan berkala;

d. Fasilitas tempat tinggal yang layak dan kendaraan petugas pandu untuk kegiatan operasional yang belum terpenuhi.

» Peluang (Opportunity)

a. Minat pengguna jasa yang tinggi sehingga berpotensi meningkatnya jumlah kunjungan kapal;

b. Kebijakan pemerintah untuk memberikan kesempatan usaha di bidang penyediaan pelayanan pemanduan kapal ataupun perawatan alur/kolam pelabuhan.

» Ancaman (Threat)

a. Kondisi pasang surut dan cuaca pada alur pelayaran yang tidak dapat diprediksi;

b. Kebijakan pemerintah mendistribusikan pandu untuk melayani pemanduan kapal pada TUKS (Terminal Untuk Kepentingan Sendiri) dan TERSUS (Terminal Khusus) wilayah sekitarnya.

Berdasarkan faktor internal dan eksternal yang didapat di atas terdapat strategi-strategi untuk memperoleh perbaikan kinerja pelayanan pemanduan kapal yang gambarkan melalui matrik analisis SWOT pada tabel 11. di bawah ini: 
Tabel 3. Matrik Analisis SWOT

\begin{tabular}{|c|c|c|}
\hline EFAS & $\begin{array}{l}\quad \text { Kekuatan (Strength) } \\
\text { 1. Ketepatan waktu pemanduan kapal } \\
\text { (approach time) yang sudah sesuai dengan } \\
\text { harapan pengguna jasa; } \\
\text { 2. SISPRO (Sistem dan Prosedur) } \\
\text { pemanduan kapal yang selalu } \\
\text { dikoordinasikan dan disosialisasikan } \\
\text { dengan baik; } \\
\text { 3. Telah adanya program pengerukan } \\
\text { alur/kolam yang dilaksanakan secara } \\
\text { berkala. }\end{array}$ & \begin{tabular}{|l} 
Kelemahan (Weakness) \\
1.
\end{tabular} \\
\hline $\begin{array}{l}\text { Peluang (Opportunity) } \\
\text { 1. Minat pengguna jasa yang tinggi sehingga } \\
\text { berpotensi meningkatnya jumlah kunjungan } \\
\text { kapal; } \\
\text { 2. Kebijakan pemerintah untuk memberikan } \\
\text { kesempatan usaha di bidang penyediaan } \\
\text { pelayanan pemanduan kapal ataupun } \\
\text { perawatan alur/kolam pelabuhan. }\end{array}$ & $\begin{array}{l}\text { Strategi - SO } \\
\checkmark \text { Mempertahankan ketepatan waktu } \\
\text { pemanduan kapal (approach time) untuk } \\
\text { meningkatkan kunjungan kapal dari } \\
\text { meningkatnya minat pengguna jasa; } \\
\checkmark \text { Memberikan kesempatan usaha bagi para } \\
\text { investor pada bidang pelayanan } \\
\text { pemanduan kapal dan perawatan } \\
\text { alur/kolam pelabuhan secara terbuka } \\
\text { dengan selalu berpedoman pada SISPRO } \\
\text { (Sistem dan Prosedur) yang berlaku. }\end{array}$ & $\begin{array}{l}\text { Strategi - WO } \\
\checkmark \text { Mengintegrasikan sistem pelayanan dokumen } \\
\text { sehingga dapat melayani potensi-potensi } \\
\text { meningkatnya jumlah kunjungan kapal dengan } \\
\text { lebih efektif dan efisien; } \\
\checkmark \text { Membuat kerjasama kerja dengan pihak } \\
\text { Direktorat Kenavigasian dan pihak kedua terkait } \\
\text { sistem kenavigasian, penyediaan kapal } \\
\text { tunda/pandu dan fasilitas-fasilitas pandu untuk } \\
\text { menunjang pelaksanaan operasional pelayanan } \\
\text { pemanduan kapal. }\end{array}$ \\
\hline \begin{tabular}{l}
\multicolumn{1}{c}{ Ancaman (Threat) } \\
1. Kondisi pasang surut dan cuaca pada alur \\
pelayaran yang tidak dapat diprediksi; \\
2. Kebijakan pemerintah mendistribusikan \\
pandu untuk melayani pemanduan kapal \\
pada TUKS (Terminal Untuk Kepentingan \\
Sendiri) dan TERSUS (Terminal Khusus) \\
wilayah sekitarnya.
\end{tabular} & $\begin{array}{l}\text { Strategi - ST } \\
\checkmark \text { Memberikan perawatan dengan } \\
\text { melaksanakan program pengerukan pada } \\
\text { alur pelayaran untuk mengatasi kondisi } \\
\text { pasang dan surut; } \\
\checkmark \text { Membuat SISPRO (Sistem dan Prosedur) } \\
\text { Pelayanan Pemanduan Kapal dengan } \\
\text { mempertimbangkan kebutuhan pandu dan } \\
\text { tunda terhadap kunjungan kapal antara } \\
\text { Terminal Umum, TUKS (Terminal Untuk } \\
\text { Kepentingan Sendiri) dan TERSUS } \\
\text { (Terminal Khusus) wilayah sekitarnya. }\end{array}$ & \begin{tabular}{|l}
\multicolumn{1}{c}{ Strategi - WT } \\
$\checkmark$ Berkoordinasi dan bekerjasama dengan \\
Direktorat Kenavigasian untuk sistem informasi \\
terhadap kondisi cuaca dan pasang surut pada \\
keintegrasian sistem pelayanan dokumen; \\
$\checkmark$ Menyediakan cadangan kapal tunda/pandu dan \\
memberikan fasilitas-fasilitas petugas pandu \\
untuk melayani kapal-kapal yang melakukan \\
kegiatan pemanduan, baik pada Terminal Umum \\
ataupun pada TUKS (Terminal Untuk \\
Kepentingan Sendiri) dan TERSUS (Terminal \\
Khusus) wilayah sekitarnya.
\end{tabular} \\
\hline
\end{tabular}

\section{Kesimpulan Dan Saran}

\subsection{Kesimpulan}

Berdasarkan hasil analisis dan pembahasan yang telah dikemukakan, maka hasil penelitian ini dapat disimpulkan sebagai berikut :

1. Secara umum kegiatan operasional yang berlaku di Pelabuhan Tanjung Perak selama 24 jam setiap hari selama 7 hari dalam seminggu dan meningkatnya kunjungan kapal dari tahun 2014 di Pelabuhan Tanjung Perak sebanyak 458 kapal merupakan suatu gambaran untuk adanya perubahan pelayanan yang lebih baik. Kondisi eksisting pada Pelabuhan Tanjung Perak telah didapatkan bahwa terdapat 9 (sembilan) terminal dengan waktu tunggu (waiting time) paling lama 2-3 jam sebanyak 5.883 kapal dari 8.956 kunjungan kapal dalam 1 tahun. Sehingga dinilai saat ini waktu tunggu (waiting time) lebih dari 2 jam untuk mendapat pelayanan pemanduan kapal, hal ini tidak sesuai dengan standar yang telah ditetapkan pada Standar Kinerja Pelayanan Operasional Pelabuhan.

2. Persepsi pengguna jasa dan stakeholder terkait kinerja pelayanan pemanduan kapal yang diolah dan dianalisa menggunakan metode IPA (Importance Performance Analyisis) pada Excel didapat hasil rekapitulasi bahwa persepsi pengguna jasa tidak puas terhadap kinerja pelayanan pemanduan kapal dan menilai pelayanan pemanduan adalah faktor yang penting.

3. Faktor-faktor yang dapat mempengaruhi kinerja pelayanan kapal adalah atribut prioritas utama yang menurut persepsi pengguna jasa memiliki tingkat kepentingan yang tinggi akan tetapi tingkat kinerjanya rendah adalah:

a. Ketepatan pelayanan dokumen

Sudah adanya sistem yang terintegrasi pada pelayanan dokumen akan tetapi masih belum diterapkan sehingga mengakibatkan rawan terjadinya pungutan liar (pungli);

b. SBNP (Sarana Bantu Navigasi Pelayaran)

Tersedianya sistem kenavigasian akan tetapi tidak digunakan untuk memonitoring dan pengawasan sehingga mempermudah pelaksanaan pemanduan kapal yang lebih baik; 
c. Ketersediaan kapal tunda/pandu

Belum adanya cadangan kapal tunda/pandu apabila terjadi kerusakan atau perawatan berkala, sehingga kapal-kapal yang membutuhkan pelayanan pemanduan harus menunggu kapal tunda/pandu untuk waktu yang cukup lama;

d. Ketersediaan fasilitas untuk petugas pandu

Fasilitas yang belum tersedia untuk kegiatan operasional pelaksanaan pemanduan kapal dan kelayakan tempat tinggal bagi petugas pandu laut di lapangan, sehingga hanya ditempatkan di Stasiun Pandu (Pilot Station).

4. Strategi-strategi perbaikan kinerja pelayanan pemanduan pada penelitian ini dengan menggunakan metode analisis SWOT (Streght, Weakness, Opportunity dan Threat) secara subjektif yang didapat dari hasil analisis IPA (Importance Performance Analysis) dan berdasarkan hasil wawancara di lapangan yaitu sebagai berikut:

" Strategi S-O (Strength - Opportunity)

a. Mempertahankan ketepatan waktu pemanduan kapal (approach time) untuk meningkatkan kunjungan kapal dari meningkatnya minat pengguna jasa untuk menggunakan jasa pemanduan kapal, dengan cara tidak merubah sistem pergerakan pemanduan kapal atau menjadikan tolak ukur terhadap aspek kinerja pelayanan pemanduan lainnya;

b. Memberikan kesempatan usaha bagi para investor pada bidang pelayanan pemanduan kapal dan perawatan alur/kolam pelabuhan secara terbuka dengan selalu berpedoman pada SISPRO (Sistem dan Prosedur) yang ada berlaku, sehingga menambah kompetitor untuk meningkatkan daya saing operator pada kinerja pelayanan pemanduan kapal.

» Strategi S-T (Strength - Threat)

a. Memberikan perawatan dengan melaksanakan program pengerukan yang dilaksanakan oleh pihak kedua pada APBS (Alur Pelayaran Barat Surabaya) untuk mengatasi kondisi pasang surut yang tidak dapat diprediksi, sehingga dapat menyebabkan terjadinya resiko kecelakaan kapal yang diakibatkan karena kedangkalan dan lebar alur yang belum memadai;

b. Membuat SISPRO (Sistem dan Prosedur) Pelayanan Pemanduan Kapal dengan mempertimbangkan aspek kebutuhan pandu dan tunda berdasarkan evaluasi dan koordinasi terhadap kunjungan kapal antara Terminal Umum, TUKS (Terminal Untuk Kepentingan Sendiri) dan TERSUS (Terminal Khusus) wilayah sekitarnya, sehingga tidak adanya keterbatasan pandu dan tunda untuk melayani kapal.

" Strategi W-O (Weakness - Opportunity)

a. Mengintegrasikan sistem pelayanan dokumen sehingga dapat melayani potensi-potensi meningkatnya jumlah kunjungan kapal dengan menerapkan sistem inaportnet dan NSW (National Single Window) secara online agar menghilangkan adanya pungutan liar (pungli) pada pengguna jasa dan memudahkan pengawasan pemerintah terhadap kinerja pelayanan;

b. Membuat kerjasama kerja dengan pihak Direktorat Kenavigasian dan pihak kedua terkait pengoperasian VTS (Vassel Traffic Service) untuk monitoring dan melakukan pengawasan pemanduan, penyediaan kapal dan fasilitas-fasilitas pandu untuk menunjang pelaksanaan operasional pelayanan pemanduan kapal baik untuk kendaraan operasional ataupun untuk kelayakan tempat tinggal pandu laut di lapangan.

" Strategi $\mathrm{W}-\mathrm{T}$ (Weakness - Threat)

a. Berkoordinasi dan bekerjasama dengan Direktorat Kenavigasian untuk sistem informasi terhadap kondisi cuaca dan pasang surut pada keintegrasian sistem pelayanan dokumen, sehingga kapal-kapal yang akan melakukan kegiatan pemanduan dapat mengetahui kondisi cuaca dan pasang surut di lapangan pada saat mengajukan dokumen PPKB (Permintaan Pelayanan Kapal dan Barang);

b. Menyediakan cadangan kapal tunda/pandu dan memberikan fasilitas-fasilitas petugas pandu untuk melayani kapal-kapal yang melakukan kegiatan pemanduan baik pada Terminal Umum ataupun pada TUKS (Terminal Untuk Kepentingan Sendiri) dan TERSUS (Terminal Khusus) wilayah sekitarnya.

\subsection{Saran}

Berdasarkan kesimpulan di atas, maka dapat dikemukakan beberapa saran, yaitu :

a. Agar mendapatkan hasil penelitian yang lebih baik, sebaiknya dilakukan evaluasi kinerja pelaksanaan pemanduan kapal secara teknis pada masing-masing terminal di Pelabuhan untuk mengetahui faktor-faktor apa saja yang menjadi hambatan-hambatan di lapangan berdasarkan persepsi dari pihak kapal; 
b. Agar mendapatkan hasil penelitian yang lebih lengkap, sebaiknya dilakukan analisis perhitungan waktu tunggu (waiting time) dengan waktu pelayanan pemanduan dari waktu tunggu pandu (waiting time pilot) hingga waktu pemanduan (approach time) kapal serta perhitungan waktu efektif (effective time) banding waktu selama kapal di dermaga (berthing time) dari ikat tali sampai lepas tali kapal pada masing-masing terminal di Pelabuhan yang mengacu pada standar-standar yang telah ditentukan dengan didukung oleh data-data dan metode-metode yang reliabel.

\section{Daftar Pustaka}

[1] M. A. Ardyana, Pengaruh Kualitas Pelayanan Kapal Terhadap Kepuasan Pengguna Jasa PT. Pelabuhan Indonesia III (Persero) Cabang Tanjung Perak (Studi pada Jasa Pemanduan Kapal). 2015.

Use the "Insert Citation" button to add citations to this document.

[2] Arikunto. (2002). Prosedur Suatu Penelitian : Pendekatan Praktek. Jakarta: Rineka Cipta.

[3] Aritonang, L. R. (2005). Kepuasan Pelanggan. Pengukuran dan Penganalisisan dengan SPSS. Jakarta: Gramedia Pustaka Utama.

[4] Bambang Susantono, P. (2013). Transportasi dan Investasi (Tantangan dan Perspektif Multidimensi). Kompas.

[5] Brandt, D. (2000). An “Outside-In" Approiach to Determining Customer-Driven Priorities for Improvement and Innovation. White Paper Series.

[6] Danik. (n.d.). Retrieved from http://danik-pelindo-perak.tripod.com/fasilitas.htm

[7] Hartini, C. V. (2014). Kajian Kinerja Pelayanan Operasional Pelabuhan Tanjung Perak.

[8] Hasan, M. I. (2002). Pokok-Pokok Metodologi Penelitian dan Aplikasinya. Jakarta: Ghali Indonesia.

[9] J.C, Martilla J.A \& James. (1977). Journal of Marketing. 1, Vol. 41.

[10] John A. Martila and James C. John. (1997). The Analysis of The Importance and Satisfaction level of The Customers.

[11] Kementerian Perhubungan. (2011). Surat Keputusan Direktur Jenderal Perhubungan Laut Nomor : UM.002/38/18/DJPL-11 Tentang Standar Kinerja Pelayanan Operasional Pelabuhan. Jakarta: Direktorat Jenderal Perhubungan Laut.

[12] Kementerian Perhubungan. (2011). Surat Keputusan Kepala Kantor Otoritas Pelabuhan III Tanjung Perak Surabaya Nomor HK.208/01/14/OP.Tpr-11 tentang Pedoman SISPRO (Sistem dan Prosedur) Pelayanan Jasa Pemanduan Wilayah Perairan Wajib Pandu di Lingkungan Otoritas Pelabuhan III Tanjung Perak. Surabaya: Kantor Otoritas Pelabuhan Utama Tanjung Perak.

[13] Martinez, C. (2003). Evaluation Report: Tools Cluster Networking Meeting. Arizona: CenterPoint Institute, Inc.

[14] Massnick, F. (1997). The Customer is CEO, How to Measure What Your Customer Want and Make Sure They Get it.

[15] Nazir, M. (1998). Metode Penelitian. Jakarta: Ghalia Indonesia.

[16] Oliver, R. L. (1997). Satisfaction: A Behavioral Perpective On The Consumer.

[17] Peraturan Menteri Perhubungan No. 57. (2015). Pemanduan dan Penundaan Kapal. Kementerian Perhubungan.

[18] Perhubungan, B. P. (2003). Studi Peningkatan Kualitas Pelayanan Pelabuhan Internasional Hub, Internasional dan Nasional. Kementerian Perhubungan.

[19] Rangkuti, F. (2003). Measuring Customer Satisfaction. Jakarta: Gramedia Pustaka Utama.

[20] Rangkuti, F. (2005). Analisa SWOT Teknik Membedah Kasus Bisnis. Jakarta: Gramedia Pustaka.

[21] Saleh, E. F. (2011). Analisis Pengaruh Kualitas Layanan Terhadap Kepuasan Pelanggan (Studi di PT. Pelindo III Cab. Tg. Emas Semarang).

[22] Santoso, S. (2003). Mengatasi Berbagai Masalah Statistik Dengan SPSS. Jakarta: PT. Elex Media Komputindo.

[23] Santoso, S. (2004). Buku Statistik Parametrik (Cetakan Keempat). Jakarta: PT. Elex Media Kumputindo.

[24] Setiono, B. A. (2010). Analisis Faktor-Faktor yang Memperngaruhi Kinerja Pelabuhan.

[25] Simamora, B. (2004). Riset Pemasaran. Jakarta: Gramedia Pustaka Utama.

[26] Sugiyono. (2002). Metode Penelitian Administrasi. Jakarta: PT. Gramedia Pustaka Utama.

[27] Sujono. (1998). Pengajaran Matematika Untuk Sekolah Menengah. Jakarta: Departemen Pendidikan dan Kebudayaan Direktorat Jendral Pendidikan Tinggi Proyek Pengembangan Lembaga Pendidikan Tenaga Kependidikan.

[28] Suprapto, J. (2001). Pengukuran Tingkat kepuasan pelanggan untuk Menaikkan Pangsa Pasar.

[29] T.M. Latu \& A.M. Everett. (2000). Review of Satisfaction Research and Measurement Approaches. Wellington, New Zealand: Department of Conservation.

[30] Triyono, A. (2013). Kajian Kinerja dan Rencana Pengembangan Pelabuhan Umum Gresik.

[31] Undang-Undang RI Nomor 17. (2008). Pelayaran. Kementerian Perhubungan. 
[32] Wibowo, H. (2010). Analisis Faktor-Faktor yang Mempengaruhi Waktu Tunggu Kapal di Pelabuhan Tanjung Emas Semarang. 